\title{
Mercury in coniferous and deciduous upland forests in northern New England, USA: implications of climate change
}

\author{
J. B. Richardson ${ }^{1,2}$ and A. J. Friedland ${ }^{2}$ \\ ${ }^{1}$ Department of Earth Science, Dartmouth College, Hanover, NH 03755, USA \\ ${ }^{2}$ Environmental Studies Program, Dartmouth College, Hanover, NH 03755, USA \\ Correspondence to: J. B. Richardson (justin.richardson@ dartmouth.edu)
}

Received: 2 June 2015 - Published in Biogeosciences Discuss.: 22 July 2015

Revised: 28 October 2015 - Accepted: 11 November 2015 - Published: 26 November 2015

\begin{abstract}
Climatic changes in the northeastern US are expected to cause coniferous stands to transition to deciduous stands over the next hundred years. Mercury $(\mathrm{Hg})$ sequestration in forest soils may change as a result. In order to understand potential effects of such a transition, we studied aboveground vegetation and soils at paired coniferous and deciduous stands on eight mountains in Vermont and New Hampshire, USA. Organic horizons at coniferous stands accumulated more total $\mathrm{Hg}\left(\mathrm{THg} ; 42 \pm 6 \mathrm{~g} \mathrm{ha}^{-1}\right)$ than deciduous stands $\left(30 \pm 4 \mathrm{~g} \mathrm{ha}^{-1}\right)$. Total $\mathrm{Hg}$ pools in the mineral horizons were similar for coniferous $\left(46 \pm 8 \mathrm{~g} \mathrm{ha}^{-1}\right)$ and deciduous stands $\left(45 \pm 7 \mathrm{~g} \mathrm{ha}^{-1}\right)$. Soil properties $(\mathrm{C}, \%$ clay, and $\mathrm{pH}$ ) explained $56 \%$ of the variation in mineral soil $\mathrm{Hg}$ concentration when multiply regressed. Foliar and bole wood $\mathrm{Hg}$ concentrations were generally greater for coniferous species than deciduous species. Using allometric equations, we estimated that aboveground accumulation of $\mathrm{Hg}$ in foliage and woody biomass was similar between vegetation types but that coniferous stands have significantly smaller annual litterfall fluxes $\left(0.03 \mathrm{~g} \mathrm{ha}^{-1} \mathrm{yr}^{-1}\right)$ than deciduous stands $\left(0.24 \mathrm{~g} \mathrm{ha}^{-1} \mathrm{yr}^{-1}\right)$. We conclude that organic horizon $\mathrm{Hg}$ accumulation is influenced by vegetation type but mineral horizon $\mathrm{Hg}$ accumulation is primarily controlled by soil properties. Further investigations into the effect of vegetation type on volatilization, atmospheric deposition, and leaching rates are needed to constrain regional $\mathrm{Hg}$ cycling rates.
\end{abstract}

\section{Introduction}

Forest soils play a key role in the global mercury $(\mathrm{Hg}) \mathrm{cy}-$ cle because they sequester $\mathrm{Hg}$ from both natural and human sources (Nater and Grigal, 1992; Fitzgerald et al., 1998; Driscoll et al., 2007; Streets et al., 2011). The accumulation and retention of $\mathrm{Hg}$ in upland forest soils is an integral part of $\mathrm{Hg}$ biogeochemistry. Soils ultimately control $\mathrm{Hg}$ transport to downslope riparian areas, where it can be methylated to its most toxic form, methylmercury (Aastrup et al., 1991; Lorey and Driscoll, 1999; Schwesig and Matzner, 2001; Grigal, 2003; Driscoll et al., 2007; Evers et al., 2007; Demers et al., 2013; Chalmers et al., 2014). Birds, fish, mammals, amphibians, and invertebrates across the northeastern US are reported to have elevated $\mathrm{Hg}$ concentrations in their bodies (Evers et al., 2007; Rimmer et al., 2010; Townsend and Driscoll, 2013; Richardson et al., 2015). Policy makers, resource managers, and scientists have recognized the need to limit $\mathrm{Hg}$ reaching terrestrial and aquatic organisms (USEPA, 2011). Greater knowledge of the processes that control Hg accumulation and retention in forest soils is needed to understand its fate and transport in forested ecosystems.

Climate change has the potential to alter the sequestration of $\mathrm{Hg}$ from forest soils via direct pressures (meteorological) or indirect pressures (changes to vegetation). Climate models have predicted regional increases in precipitation that could cause greater wet deposition of $\mathrm{Hg}$ (Tang and Beckage, 2010; Smith-Downey et al., 2010). Moreover, projected increases in mean annual temperatures may increase net primary productivity of vegetation in forests across the region, potentially increasing plant interception and litterfall inputs of Hg to soils (Tang and Beckage, 2010; Smith-Downey et al., 
2010). Conversely, increased mean annual temperatures and soil moisture may release $\mathrm{Hg}$ from soils by enhancing the decomposition rate of soil organic matter (SOM) or volatilization (Smith-Downey et al., 2010; Blackwell et al., 2014). Climate change could have indirect consequences on forests that may also affect $\mathrm{Hg}$ cycling. In the northeastern US, forest stands of coniferous tree genera (gymnosperms such as Abies balsamea, Picea rubens, and Pinus spp.) are expected to be succeeded by deciduous tree genera (angiosperms such as Acer spp., Fagus grandifolia, and Betula, spp.) due to the increased mean annual temperature and precipitation (Tang and Beckage, 2010). For example, coniferous vegetation has been projected to lose an estimated $71-100 \%$ of its current range to deciduous vegetation across the northeastern US by 2085 (Tang and Beckage, 2010; Tang et al., 2012). The potential shift from coniferous to deciduous type forests caused by climate change may potentially alter the accumulation and retention of $\mathrm{Hg}$ in the soil.

Vegetation type can affect many aspects of $\mathrm{Hg}$ cycling in forest soils. The varying foliar morphology and foliar biomass characteristics in different vegetation types can affect $\mathrm{Hg}$ in litterfall. For example, Juillerat et al. (2012) found coniferous species generally obtained higher $\mathrm{Hg}$ concentrations than deciduous species, which was attributed to their surface area: weight ratio and longer life span. Furthermore, physical attributes of the canopy structure of each species can directly affect the accumulation of $\mathrm{Hg}$ in foliage (Hall and St. Louis, 2004; Demers et al., 2007; Obrist et al., 2012; Blackwell and Driscoll, 2015). The greater total foliar biomass for deciduous species can cause significantly greater litterfall fluxes in deciduous-dominated forest stands (e.g., Demers et al., 2007; Juillerat et al., 2012; Obrist et al., 2012). Greater litterfall rates can increase the size of the $\mathrm{Hg}$ pool in the organic horizons (forest floor) and mineral horizons (Hall and St. Louis, 2004; Demers et al., 2007; Zhang et al., 2009; Obrist et al., 2012). Additionally, the lower N concentration and higher lignin fraction of coniferous litter is hypothesized to suppress decomposition and microbial reduction of $\mathrm{Hg}$ (Berg et al., 1993; Pokharel and Obrist, 2011; Obrist et al., 2012; Demers et al., 2013). Litter from coniferous vegetation can also affect soil properties that influence $\mathrm{Hg}$ sorption in soil (e.g., soil C and pH; Grigal, 2003; Demers et al., 2007; Obrist et al., 2011; Stankwitz et al., 2012; Richardson et al., 2013). This could increase the mobility of $\mathrm{Hg}$ and decrease the $\mathrm{Hg}$ pool in the organic and mineral horizons (Demers et al., 2007).

Quantifying the effect of vegetation type on forest soil $\mathrm{Hg}$ concentrations and pools is needed in the northeastern US due to predicted changes in forest composition under a changing climate. Previous studies have found contrasting effects from vegetation type on $\mathrm{Hg}$ cycling in forest soils (Rea et al., 2002; St. Louis et al., 2001; Demers et al., 2007; Obrist et al., 2012). The objectives of this study were (1) to quantify whether $\mathrm{Hg}$ concentrations and pools in forests and their soils are significantly different at coniferous and deciduous stands and (2) to determine whether vegetation type affects the mobility of $\mathrm{Hg}$ in soils. Information from this study can enhance landscape to regional-scale estimates of $\mathrm{Hg}$ sequestration in forest soils and better constrain $\mathrm{Hg}$ cycling in upland forest soils.

\section{Materials and methods}

\subsection{Mountain sites and forest stands}

Eight pairs of coniferous and deciduous forest stands were studied (Table 1). Forest stands were located at eight mountain sites in the deciduous-coniferous transition zone between 650 and $750 \mathrm{~m}$ above sea level. Four mountains were located on a north-south transect along the Green Mountains of Vermont, and four sites were on a separate northsouth transect along the White Mountains of New Hampshire. Sampling sites were on west-facing slopes to avoid biases from aspect. Northern New England is a temperate climate, with mean annual temperatures at the stands ranging from 6 to $10^{\circ} \mathrm{C}$ and mean annual precipitation ranging from 800 to $1300 \mathrm{~mm}$ (PRISM climate research group, 2012). The mean annual frost-free period ranges from 90 to 160 days (Soil Survey Staff, 2014).

At each mountain site, a coniferous stand and a deciduous stand within $50 \mathrm{~m}$ of each other were studied. Stands were $30 \mathrm{~m}$ diameter circles. The frequency of each species and diameter at breast height (DBH) for all trees was determined for the $707 \mathrm{~m}^{2}$ stand. Coniferous stands were inhabited with $>50 \%$ coniferous genera, and deciduous stands were inhabited by $>60 \%$ deciduous genera based upon basal area and stem frequency (Table 1). Basal area was estimated from DBH measurements (Whittaker et al., 1974). Coniferous species present were balsam fir (Abies balsamea Mill.), red spruce (Picea rubens Sarg.), and eastern hemlock (Tsuga canadensis L.). Deciduous species present were American beech (Fagus grandifolia Ehrh.), sugar maple (Acer saccharum Marsh.), red maple (Acer rubrum L.), striped maple (Acer pensylvanicum Marsh.), paper birch (Betula papyrifera Marsh.), and yellow birch (Betula alleghaniensis Britt.). Vegetation at all stands was secondary growth due to the historical clearing of the region in the 1800s and abandonment in the period from circa 1870 through 1920s (see Foster, 1992). Coniferous stands were located away from trails and logging roads, in areas that were likely difficult for timber harvesting. Using DBH of Acer saccharum, Picea rubens, and Abies balsamea at each stand, we calculated growth rates using parameters from Teck and Hilt (1991) and Kenefic and Nyland (1999). We calculated that stand ages ranged from 57 to 137 years with a mean of $88 \pm 9$ years (Lamson, 1987). These ages may vary with site edaphic characteristics.

Only sites on bench landform and well-drained soils were chosen. The soil parent material was glacial till for all stands, which was deposited during the retreat of the Laurentian 
Table 1. Forest stand descriptions.

\begin{tabular}{|c|c|c|c|c|c|c|c|c|}
\hline Site no. & $\begin{array}{r}\text { Elevation } \\
\text { a.s.1. }\end{array}$ & $\begin{array}{l}\text { Dominant } \\
\text { vegetation type }\end{array}$ & $\begin{array}{l}\text { Species } \\
\text { present* }\end{array}$ & $\begin{array}{r}\text { Stem } \\
\text { density }\end{array}$ & $\begin{array}{r}\text { Basal } \\
\text { area }\end{array}$ & $\begin{array}{r}\% \text { conifer } \\
\text { by basal area }\end{array}$ & $\begin{array}{r}\% \text { conifer } \\
\text { by frequency }\end{array}$ & $\begin{array}{l}\text { Soil taxonomy } \\
\text { (observed) }\end{array}$ \\
\hline & $\mathrm{m}$ & & & stems ha ${ }^{-1}$ & $\mathrm{~m}^{2} \mathrm{ha}^{-1}$ & $\%$ & $\%$ & \\
\hline VT 1 & & Deciduous & $\mathrm{A}, \mathrm{B}, \mathrm{C}, \mathrm{E}, \mathrm{G}$ & 329 & 14 & 4 & 22 & Frigid Typic Haplorthod \\
\hline \multirow[t]{2}{*}{ VT 2} & 704 & Conifer & $\mathrm{A}, \mathrm{B}, \mathrm{C}, \mathrm{F}, \mathrm{G}$ & 302 & 11 & 68 & 52 & Frigid Typic Haplorthod \\
\hline & & Deciduous & $\mathrm{B}, \mathrm{C}, \mathrm{D}, \mathrm{F}, \mathrm{H}$ & 243 & 12 & 0 & 6 & Frigid Typic Haplorthod \\
\hline VT 3 & 608 & Conifer & $\mathrm{A}, \mathrm{D}, \mathrm{E}, \mathrm{F}$ & 371 & 6 & 52 & 52 & Frigid Typic Haplorthod \\
\hline VT 4 & & Deciduous & $\mathrm{C}, \mathrm{D}, \mathrm{E}, \mathrm{F}, \mathrm{G}, \mathrm{H}$ & 214 & 6 & 40 & 32 & Frigid Fragic Haplorthod \\
\hline \multirow[t]{2}{*}{ NH 1} & 680 & Conifer & $\mathrm{B}, \mathrm{D}, \mathrm{E}, \mathrm{F}, \mathrm{G}, \mathrm{H}$ & 443 & 8 & 76 & 52 & Frigid Oxyaquic Haplorthod \\
\hline & & Deciduous & $\mathrm{B}, \mathrm{C}, \mathrm{D}, \mathrm{G}$ & 271 & 16 & 0 & 0 & Frigid Typic Haplorthod \\
\hline \multirow{2}{*}{ NH 2} & 641 & Conifer & $\mathrm{A}, \mathrm{B}, \mathrm{C}, \mathrm{E}, \mathrm{F}, \mathrm{G}, \mathrm{H}$ & 429 & 9 & 54 & 64 & Frigid Oxyaquic Haplorthod \\
\hline & & Deciduous & $\mathrm{A}, \mathrm{B}, \mathrm{C}, \mathrm{D}, \mathrm{E}, \mathrm{F}, \mathrm{G}$ & 357 & 11 & 2 & 4 & Frigid Typic Haplorthod \\
\hline NH 3 & 610 & Conifer & $\mathrm{A}, \mathrm{C}, \mathrm{F}, \mathrm{G}, \mathrm{H}$ & 457 & 5 & 60 & 65 & Frigid Oxyaquic Haplorthod \\
\hline
\end{tabular}

* A: Abies balsamea; B: Acer pensylvanicum; C: Acer rubrum; D: Acer saccharum; E: Betula alleghaniensis; F: Betula papyrifera; G: Fagus grandifolia; H: Picea rubens; I: Tsuga canadensis.

ice sheet in the Wisconsinan glaciation $\sim 14000$ years ago (cf. Siccama, 1974; Soil Survey Staff, 2010). Glacial till at sites NH 1-NH 4 was generally sourced from local bedrock: Bethlehem granodiorite with contributions of Concord granite, Kinsman granodiorite, and metasedimentary rocks from more northern formations (Bennett et al., 2006; Lyons et al., 1997). Glacial till at sites VT 1-VT 4 was locally sourced from the Waits River and Missisquoi formations, with additions of other metasedimentary formations (Doll et al., 1961; Ratcliffe, 2000).

\subsection{Soil and vegetation sample collection}

Late-season foliage and bole wood samples were collected from Picea rubens, Tsuga canadensis, Abies balsamea, Fagus grandifolia, Acer spp., and Betula spp. in triplicate from each forest stand in early October 2012, 2013, and 2014. Foliage was collected from branches in the middle canopy, 3-6 $\mathrm{m}$ above the ground, using a stainless steel pole saw. By not collecting upper canopy foliage, we may have underestimated foliar $\mathrm{Hg}$ concentrations because $\mathrm{Hg}$ deposition is greater in upper canopy leaves (Luyassert et al., 2002). Bole wood was sampled at DBH using an $4 \mathrm{~mm}$ increment corer. Foliage and bole wood samples were air-dried at $25^{\circ} \mathrm{C}$ for 3 weeks and milled for homogeneity. Aboveground woody biomass and foliar biomass was estimated using allometric equations for each species from studies conducted in the northeastern US and southeastern Canada (Ferrari and Sugita, 1996; Ter-Mikaelian and Korzukhin, 1997; Jenkins et al., 2003). The foliar and woody biomass for each tree was summed for an estimate of total foliar and woody biomass at each stand. Aboveground woody biomass and foliage biomass can vary with canopy geometry, tree morphology, and fitness of each tree (Ferrari and Sugita, 1996; Luyas- saert et al., 2002). However, these estimates provide an approximation of values without permanent destruction.

Annual litterfall fluxes from deciduous vegetation were assumed to be the entire foliar biomass. Annual litterfall fluxes from balsam fir and eastern hemlock were assumed to be onethird the foliar biomass because Barnes and Wagner (1981) observed average needle longevity of 3 years. Similarly, litterfall fluxes from Picea rubens was assumed to be one-fifth the foliar biomass because Barnes and Wagner (1981) observed an average needle longevity time of 5 years. The annual litterfall for each stand was calculated as the summed litterfall contribution for each tree at each stand. Leaves from trees may fall beyond the boundaries of the $707 \mathrm{~m}^{2}$ stand; thus, our litterfall values are likely overestimates (Ferrari and Sugita, 1996).

The soils at each forest stand were sampled between July and September 2012. To control for the effect of soil type on $\mathrm{Hg}$ accumulation, only Spodosols were studied. Soils were classified as Spodosols using US Soil Taxonomy guidelines (Soil Survey Staff, 2010). Soil taxonomy identification was based on soil pit descriptions and USDA-NRCS Web Soil Survey (Soil Survey Staff, 2014). First, a trench was dug to ensure an E horizon (white leached layer) and Bhs horizon (organic-matter- and iron oxide-rich layer) were present. At each forest stand, three $15 \times 15 \mathrm{~cm}$ square sections of organic horizons were separated from the underlying mineral soil and collected (see Richardson et al., 2014). Three morphological quantitative soil pits were by each master horizon $(\mathrm{E}, \mathrm{Bhs}, \mathrm{B} / \mathrm{C})$ until dense basal till was reached for each forest stand. First, a $50 \times 50 \mathrm{~cm}$ wooden frame was secured to the ground nearby by using $12 \mathrm{~cm}$ steel spikes. The organic horizons were removed using saws and clippers. Each master horizon was excavated, sieved to $<2 \mathrm{~cm}$, and weighed 
using an electronic portable scale. A $5 \mathrm{~kg}$ representative subsample was collected for each master horizon to determine field moisture content and rock fragments $0.2-2 \mathrm{~cm}$ in diameter. A separate subsample was collected from the face of each soil pit for chemical analyses. In total, 48 quantitative soil pits were excavated in this study. In the laboratory, the $15 \times 15 \mathrm{~cm}$ blocks of organic horizon were separated into Oi (litter layer), Oe (fermentation layer), and $\mathrm{Oa}$ (humified layer) horizons were separated, roots $>5 \mathrm{~mm}$ in diameter were removed, and samples were air-dried at $25^{\circ} \mathrm{C}$ to a constant mass. Organic horizon masses were calculated using oven-dried subsamples. All mineral soil samples were air-dried to a constant weight, and roots $>5 \mathrm{~mm}$ in diameter were removed. Organic horizons and mineral soil samples were milled and sieved, respectively, to $<2 \mathrm{~mm}$.

A 2:5 soil-water slurry was used to determine soil $\mathrm{pH}$. Slurries were shaken for $1 \mathrm{~h}$ using a wrist-action shaker and vacuum extracted through a Whatman 40 filter. The $\mathrm{pH}$ of the extract was measured with a $\mathrm{pH}$ meter (model 8015, VWR). The sand, silt, and clay fractions were measured using a modified Bouyoucos hydrometer method (Gee and Bauder, 1986). Loss on ignition was used to estimate \% SOM. To determine the percent loss on ignition, a $4 \mathrm{~g}$ air-dried subsample was combusted at $475^{\circ} \mathrm{C}$ for $8 \mathrm{~h}$. Total $\mathrm{C}$ concentrations in leaves, bole wood, and soil were measured using a Carlo Erba elemental analyzer. In brief, $6 \pm 1 \mathrm{mg}$ of sample ground to $<0.5 \mathrm{~mm}$ was analyzed. Each batch of 20 samples included one blank, one Atropine standard reference material (SRM), and a duplicate. Total $\mathrm{C}$ and $\mathrm{N}$ concentrations in Atropine SRMs were with $3 \%$ of its certified value and $<10 \%$ relative percent difference. Because soil samples were strongly acidic soils derived from granite and metamorphic rocks such as phyllites and schists, the contribution of $\mathrm{C}$ from calcite concentrations was presumed to be negligible. Soil $\mathrm{pH}$ and total C for each horizon are given in Supplement Table 1.

\subsection{Total Hg quantification}

Total $\mathrm{Hg}$ concentrations $(\mathrm{THg})$ for the organic and mineral soil were quantified using a direct mercury analyzer (DMA80 , Milestone Inc.) in which $100 \pm 10 \mathrm{mg}$ subsamples were weighed into steel boats and ashed at $650{ }^{\circ} \mathrm{C}$. To ensure quality, every 15 samples included a duplicate, a preparation blank, and a SRM. SRM 1547 (peach leaves) was used to quantify matrix effects for bole wood, leaf, and organic horizon samples, whereas Montana soil SRM 2711a was used for mineral soil samples (National Institute of Standards and Technology, Gaithersburg, MD). Preparation blanks were below detection limits, and duplicate variations were within $5 \%$. SRM $\mathrm{Hg}$ measurements were within $9 \%$ of their certified values. Total $\mathrm{Hg}$ values for each horizon are given in Table S1 in the Supplement.

\subsection{Exchangeable Hg quantification}

Exchangeable $\mathrm{Hg}(\mathrm{EHg})$ concentrations for the organic and mineral soil were quantified using a modified $\mathrm{Mg}\left(\mathrm{NO}_{3}\right)_{2}$ extraction for ion-exchangeable $\mathrm{Hg}$ (Eganhouse et al., 1978; Crock, 1996; Amacher, 1996). The method used $\mathrm{Mg}\left(\mathrm{NO}_{3}\right)_{2}$ instead of $\mathrm{MgCl}_{2}$ because $\mathrm{Hg}$ is able to form stable complexes with $\mathrm{Cl}^{-}$ions in solution (Schuster, 1991). We chose to investigate exchangeable $\mathrm{Hg}$ to consider dissolved $\mathrm{Hg}$ transport, rather than transport of $\mathrm{Hg}$ by dissolved organic compounds. In brief, $1 \mathrm{~g}$ soil was shaken in $10 \mathrm{~mL}$ of $0.1 \mathrm{M}$ $\mathrm{Mg}\left(\mathrm{NO}_{3}\right)_{2}$ for $24 \mathrm{~h}$. Samples were centrifuged at $3000 \mathrm{rpm}$ for $20 \mathrm{~min}$, and the supernatant was decanted. The slurry was rinsed with $10 \mathrm{~mL}$ of $5 \%$ ethanol, centrifuged, and decanted again. A subsample of $100 \mathrm{mg}$ of combined extraction supernatant and rinse supernatant was analyzed for $\mathrm{Hg}$ concentration using a DMA-80 (Milestone Inc.) in quartz boats. Every 15 samples included a duplicate, a preparation blank, and a $\mathrm{SRM}$ of $\mathrm{Hg}$ in solution. Preparation blanks were below detection limits, and duplicate variations were within $10 \%$. SRM $\mathrm{Hg}$ measurements were within $10 \%$ of their certified values.

\subsection{Statistical analyses}

Descriptive statistics were calculated in MATLAB. The variations in $\mathrm{THg}$ and $\mathrm{EHg}$ concentration and pools in the organic and mineral horizons were compared between vegetation types (coniferous and deciduous) using a paired sample $t$ test. Stepwise linear regressions and multiple regressions were used to explore relationships between $\mathrm{THg}$ and $\mathrm{EHg}$ concentrations with other continuous variables $(\mathrm{pH}, \%$ clay, soil C, latitude, and longitude).

\section{Results and discussion}

\subsection{Forest soil properties}

\subsubsection{Soil physical properties}

Forest soil physical properties were generally similar at coniferous and deciduous stands. Soils were well drained or excessively drained, sandy loam-textured Spodosols. The Oi and Oe horizon thicknesses were similar for both vegetation types, but Oa horizons were significantly thicker for coniferous stands $(11.3 \pm 1.5 \mathrm{~cm})$ compared with deciduous stands $(6.1 \pm 0.5 \mathrm{~cm} ; p<0.05)$. Although the thicknesses did vary significantly, the dry weight mass of the summed organic horizons was similar between vegetation types. Organic horizon thicknesses are similar to other studies conducted in this region (Juillerat et al., 2012; Richardson et al., 2013). Thicknesses of the mineral horizons $(\mathrm{E}, \mathrm{Bhs}$, and $\mathrm{B} / \mathrm{C})$ were similar for coniferous and deciduous stands. Mineral soil bulk density and texture were similar for all horizons for both vegetation types. Texture was dominated by sand, ranging from 49 to $88 \%$ (Table S1). In addition, the clay fraction 
was low, ranging from 1 to $11 \%$, which is similar to values reported in other studies in this region (Johnson and Petras, 1998; Juillerat et al., 2012). However, the \% clay was significantly lower in the E horizons $(5.2 \pm 0.4 \%)$ than in the Bhs $(7.5 \pm 0.5 \%)$ and $\mathrm{B} / \mathrm{C}$ horizons $(6.5 \pm 0.6 \% ; p<0.05)$. We attribute the difference in clay fraction to accumulation of aluminum and iron oxyhydroxides in the Bhs horizon (do Valle et al., 2005). This finding suggests that the soil samples in this study were comparable among all stands.

\subsubsection{Soil chemical properties}

The mean soil $\mathrm{pH}$ values were similar to those reported in Juillerat et al. (2012). Soil pH was significantly lower for the $\mathrm{Oe}, \mathrm{Oa}$, and $\mathrm{B} / \mathrm{C}$ horizons at coniferous stands than at deciduous stands (Fig. 1). Soil C concentrations in the organic and mineral horizons were similar to Juillerat et al. (2012) and Obrist et al. (2011). Soil C concentration was significantly greater for Oa horizons at coniferous stands than at deciduous stands (Fig. 1). Soil $\mathrm{C}$ pools in the Oi and Oa horizons were significantly greater at coniferous stands than at deciduous stands (Fig. 1).

Our findings show that coniferous vegetation has a significant impact on soil $\mathrm{pH}$ and $\mathrm{C}$ concentration in the organic horizons. However, we did not observe these differences for mineral soil horizons. Our results show that coniferousdominated stands have greater $\mathrm{C}$ storage in their organic horizons than do deciduous stands. The cause of the higher $\mathrm{C}$ in the Oa horizon at coniferous stands was unclear. It may have been caused by slower decomposition. It is generally accepted that litter from coniferous vegetation causes greater acidity in the organic horizon (cf. Pritchett and Fisher, 1987). In addition, coniferous litter is more recalcitrant because of its lower nutrient quality (lower \% $\mathrm{N}$ and higher lignin content), which makes it less susceptible to microbial decomposition (McClaugherty et al., 1985; Berg et al., 1993; Moore et al., 1999; Talbot et al., 2012), allowing for greater accumulation of soil C (Fig. 1). The greater C pool at coniferous stands implies that a future shift from coniferous to deciduous vegetation could reduce the accumulation of $\mathrm{C}$ in the organic horizon of forest soils. Due to the strong link between $\mathrm{C}$ and $\mathrm{Hg}$, smaller $\mathrm{C}$ pools could reduce the storage capacity of $\mathrm{Hg}$ in the organic horizons at deciduous stands. However, Demers et al. (2013) suggested that storage capacity of $\mathrm{Hg}$ is not limited by $\mathrm{C}$ but rather by $\mathrm{S}$ that coincides with $\mathrm{C}$ in SOM nonlinearly (i.e., $\mathrm{S}$ becomes limiting in soils with high $\mathrm{C}$ concentration). The effect of decreased $\mathrm{C}$ in soils needs further attention to determine if its relation to $\mathrm{Hg}$ is direct or indirect.

\subsection{Hg concentrations and pools in forest soils}

\subsubsection{Total $\mathrm{Hg}$ in forest soils}

We observed that organic horizons in coniferous stands have greater $\mathrm{Hg}$ concentrations and greater $\mathrm{Hg}$ pools than in deciduous stands, primarily in the Oi, Oe, and Oa horizons. The mean organic horizon $\mathrm{THg}$ concentration was $179 \mu \mathrm{g} \mathrm{kg}^{-1}$, and mean mineral horizon $\mathrm{THg}$ concentration was $64 \mu \mathrm{g} \mathrm{kg}^{-1}$. The $\mathrm{THg}$ concentrations were similar to those observed in forest soils in the northeastern US (e.g., Juillerat et al., 2012; Stankwitz et al., 2012; Richardson et al., 2013). Total Hg concentrations were significantly greater for the $\mathrm{Oi}, \mathrm{Oe}$, and $\mathrm{Oa}$ horizons at coniferous stands than at deciduous stands (Fig. 2). The summed organic horizon $\mathrm{THg}$ pools were greater for coniferous stands $\left(53 \pm 10 \mathrm{~g} \mathrm{ha}^{-1}\right)$ than for deciduous stands $\left(30 \pm 6 \mathrm{~g} \mathrm{ha}^{-1}\right)$. This pattern was largely driven by differences in the Oa horizons, in which Oa $\mathrm{Hg}$ pools at coniferous stands were $38 \pm 6 \mathrm{~g} \mathrm{ha}^{-1}$, whereas deciduous stands were only $21 \pm 4 \mathrm{~g} \mathrm{ha}^{-1}$. Mineral soil $\mathrm{THg}$ pools were similar for coniferous stands $\left(46 \pm 8 \mathrm{~g} \mathrm{ha}^{-1}\right)$ and deciduous stands $\left(45 \pm 7 \mathrm{~g} \mathrm{ha}^{-1}\right)$. Despite similar mineral soil pools, the total soil profile of $\mathrm{Hg}$ pools was greater at coniferous stands $\left(90 \pm 13 \mathrm{~g} \mathrm{ha}^{-1}\right)$ than at deciduous stands $\left(75 \pm 5 \mathrm{~g} \mathrm{ha}^{-1}\right)$.

Organic horizon $\mathrm{Hg}$ concentrations and pools may be greater at coniferous stands than at deciduous stands due to differences in physicochemical properties. The organic horizons at coniferous stands may receive less UV radiation, potentially decreasing photoreduction and volatilization of $\mathrm{Hg}$ (Carpi and Lindberg, 1997; Schlüter, 2000; Gabriel and Williamson, 2004). However, the soil properties related to $\mathrm{Hg}$ accumulation were significantly different at coniferous stands when compared with deciduous stands. Total C concentrations were greater for the Oa horizon at coniferous stands. Total $\mathrm{Hg}$ concentrations in the organic and mineral horizons were regressed with soil $\mathrm{C}, \mathrm{pH}, \%$ clay, latitude, and longitude using stepwise linear regressions and multiple regressions. Concentrations of $\mathrm{THg}$ in the organic horizons were weakly explained by soil $\mathrm{C}$ and $\mathrm{pH}$, accounting for only $24 \%$ of the variation (Table 2). These weak to poor correlations suggest other processes are responsible for $\mathrm{THg}$. Based on the vertical $\mathrm{THg}$ distribution in the organic horizons shown in Fig. 2, the $\mathrm{THg}$ concentrations are dependent on the vegetation type and degree of decomposition. Of the explanatory variables examined by stepwise linear regressions, only soil $\mathrm{C}, \mathrm{pH}$, and \% clay were significant for mineral horizons (Table 2). For the mineral soil, soil $\mathrm{C}$ had the greatest explanatory power, and when multiply regressed with $\%$ clay and $\mathrm{pH}$, the variables explained $56 \%$ of the variation in THg (Table 2). This correlation suggests that accumulation of $\mathrm{Hg}$ is primarily driven by sorption, which is controlled by soil $\mathrm{C}, \%$ clay, and $\mathrm{pH}$, and matches observations by Obrist et al. (2011), Juillerat et al. (2012), Richardson et al. (2013), and Yu et al. (2014). However, nearly $40 \%$ of the 


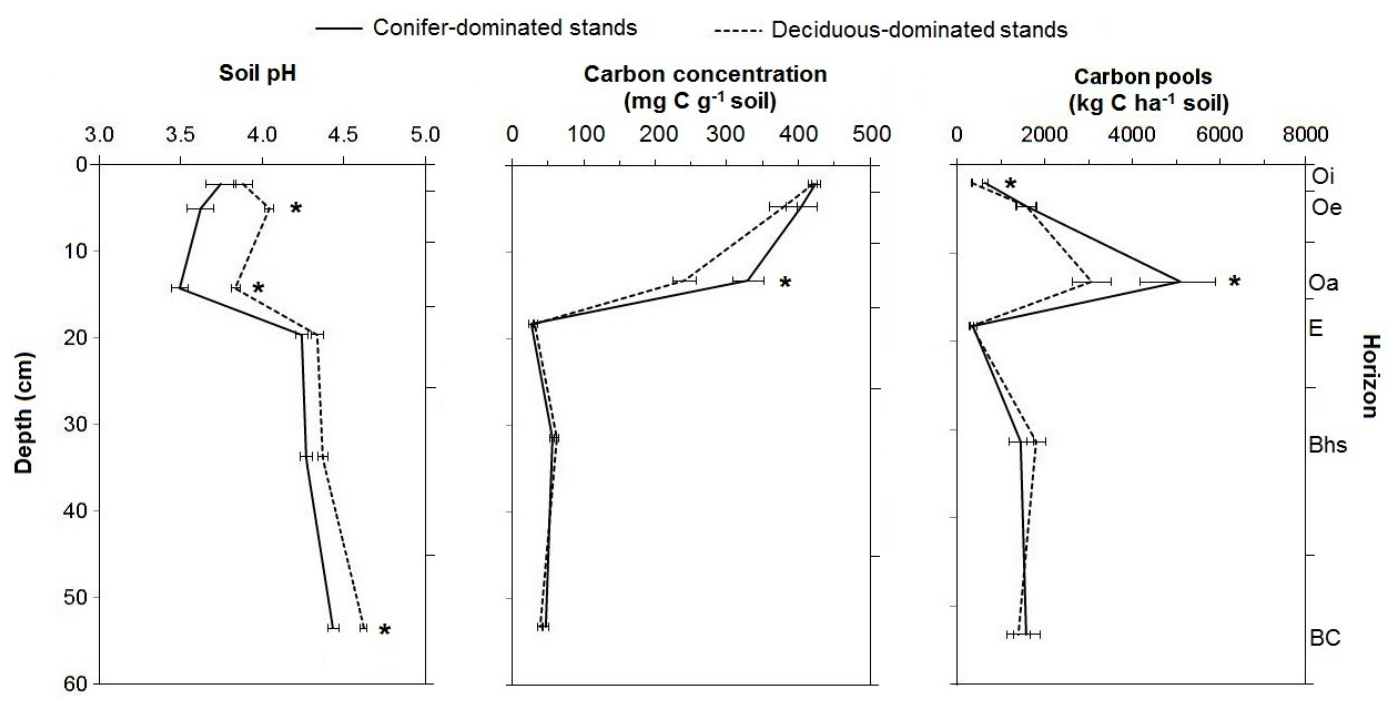

Figure 1. Soil pH, carbon concentration, and carbon pools for soil horizons at conifer- and deciduous-dominated stands. Mean values are given \pm 1 standard error. An asterisk indicates a significant difference using two-sample $t$ tests $(P<0.05)$.

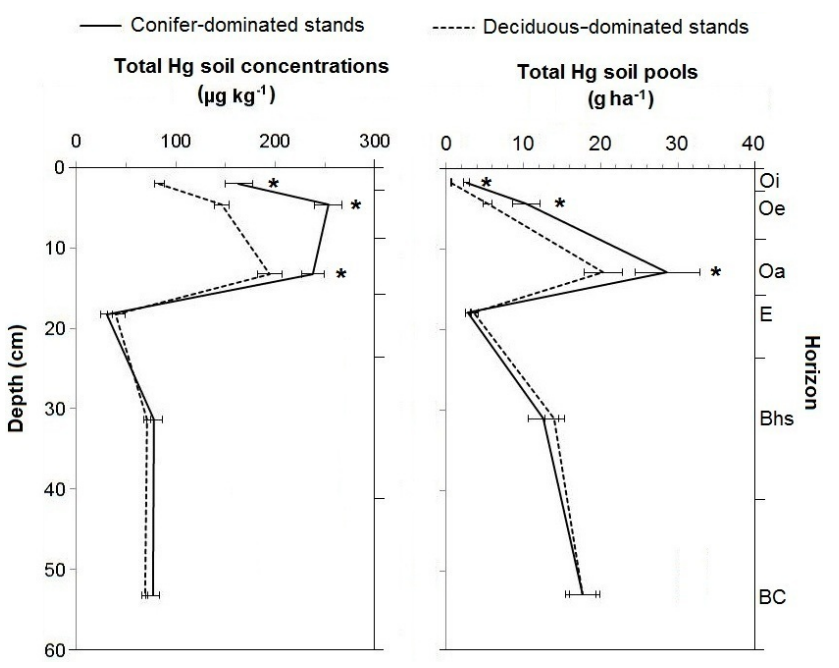

Figure 2. Total $\mathrm{Hg}(\mathrm{THg})$ concentrations in organic and mineral horizons at conifer- and deciduous-dominated forest stands. Mean values are given \pm 1 standard error. An asterisk indicates a significant difference using two-sample $t$ tests $(P<0.05)$.

variation in the mineral soil and $76 \%$ of the variation in the organic horizons remains unexplained and could be due to other unconstrained variables; hydrology and sesquioxides are two prime examples. Sesquioxides, such as aluminum and iron oxyhydroxides, are important inorganic surfaces that may sorb $\mathrm{Hg}$ directly, or provide surfaces for organomineral complexation (Garbriel and Williamson, 2004; do Valle et al., 2005). These are particularly of interest for the Bhs horizons, which have accumulations of both sesquioxides and SOM.
It is possible that soils under coniferous vegetation at the most southern sites would accumulate more $\mathrm{Hg}$ than at the most northern sites due to a longer growing season. In addition, the soils of the White Mountains of New Hampshire may receive more atmospheric deposition of $\mathrm{Hg}$ than the Green Mountains in Vermont (Miller et al., 2005). However, we did not find a significant correlation for $\mathrm{THg}$ with longitude or latitude. This suggests that longitude and latitude did not affect accumulation consistently across the eight sites or that there was not a large enough sample size or difference to detect a significant trend with latitude or mountain range.

There are landscape-scale and regional-scale ramifications for greater $\mathrm{Hg}$ sequestration in forest soils underlying coniferous stands. First, it implies that a shift from coniferous to deciduous vegetation could reduce forest soil $\mathrm{Hg}$ pools in the study region by $24 \%$. Tang et al. (2012) predicted that climatic changes could reduce coniferous stands (Abies balsamea and Picea rubens) by $\sim 80 \%$ in New England using the LPJ-GUESS model. Moreover, Tang and Beckage (2010) calculated a 71-100\% loss of coniferous forests in northern New England by the year 2085 using the BIOME4 model. Tang and Beckage (2010) estimated that $\sim 2.2$ million ha of coniferous forests will transition to deciduous forests of northern hardwoods across northern New England by the year 2085. Our calculations project a $29 \%$ reduction $\left(12 \mathrm{~g} \mathrm{ha}^{-1}\right)$ in $\mathrm{Hg}$ accumulation in upland forests. When extrapolated across the region, $27 \mathrm{t}$ less $\mathrm{Hg}$ would be sequestered in forest soils as an indirect consequence of climate change. The reduced accumulation and retention may mean that less $\mathrm{Hg}$ is sequestered from the atmosphere or that $\mathrm{Hg}$ may leach faster into watersheds during the transition period (Aastrup et al., 1991; Schwesig and Matzner, 2001). 
Table 2. Displayed are $R^{2}$ values for stepwise and multiple linear regressions of site location and select soil properties with total $\mathrm{Hg}$ (THg) and exchangeable $\mathrm{Hg}(\mathrm{EHg})$ concentrations for organic and mineral horizons.

\begin{tabular}{|c|c|c|c|c|c|}
\hline \multirow{2}{*}{$\begin{array}{l}\text { Stepwise linear } \\
\text { regressions }\end{array}$} & & \multicolumn{2}{|c|}{ Organic horizons } & \multicolumn{2}{|c|}{ Mineral horizons } \\
\hline & & $\mathrm{THg}$ & $\mathrm{EHg}$ & $\mathrm{THg}$ & $\mathrm{EHg}$ \\
\hline & & $\left(\mu \mathrm{g} \mathrm{kg}^{-1}\right)$ & $\left(\mu \mathrm{g} \mathrm{kg}^{-1}\right)$ & $\left(\mu \mathrm{g} \mathrm{kg}^{-1}\right)$ & $\left(\mu \mathrm{g} \mathrm{kg}^{-1}\right)$ \\
\hline Soil C & $\left(\mathrm{g} \mathrm{kg}^{-1}\right)$ & $0.19^{*}$ & n.s. ${ }^{b}$ & $0.37^{* *}$ & $0.45^{* *}$ \\
\hline$\%$ clay & $\left(\mathrm{g} \mathrm{g}^{-1}\right)$ & N/A & N/A & $0.17^{*}$ & n.s. \\
\hline $\mathrm{pH}$ & $\log$ units & $0.21^{*}$ & n.s. & $0.13^{*}$ & $0.36^{* *}$ \\
\hline Latitude & d.d. ${ }^{\mathrm{a}}$ & n.s. & n.s. & n.s. & n.s. \\
\hline Longitude & d.d. ${ }^{\mathrm{a}}$ & n.s. & n.s. & n.s. & n.s. \\
\hline Multiple regressions variables: & & Soil C, $\mathrm{pH}$ & - & Soil C, \% clay, $\mathrm{pH}$ & Soil $\mathrm{C}, \mathrm{pH}$ \\
\hline & & $0.24^{*}$ & - & $0.56^{* *}$ & $0.33^{* *}$ \\
\hline
\end{tabular}

${ }^{\text {a }}$ Decimal degrees. ${ }^{*}=p<0.05,{ }^{* *}=p<0.001 .{ }^{\mathrm{b}}$ n.s. indicates not significant at the $p>0.05$ statistical level.

\subsubsection{Exchangeable $\mathrm{Hg}$ in forest soils}

Quantifying the exchangeability of $\mathrm{Hg}$ is important when considering its mobility in the soil profile. The objective of the extraction process used was to exchange $\mathrm{Hg}^{+2}$ from sorption sites with $\mathrm{Mg}^{+2}$. The EHg concentrations were nearly uniform with depth, ranging between 1.1 and $9.8 \mu \mathrm{g} \mathrm{kg}{ }^{-1}$. Our results show EHg concentrations were similar for coniferous and deciduous stands in most soil horizons (Fig. 3). By dividing $\mathrm{EHg}$ concentrations by the $\mathrm{THg}$ concentrations, we are able to examine the relative fraction of exchangeable $\mathrm{Hg}$. In Fig. 3, E horizons have a significantly greater exchangeability than all other organic and mineral horizons. However, $\% \mathrm{EHg}$ was similar for coniferous and deciduous stands in all horizons (Fig. 3). On the basis of our results, $\mathrm{Hg}$ was strongly complexed in soil, regardless of vegetation type. Thus, a shift from a coniferous to a deciduous stand would not increase $\mathrm{Hg}$ mobility in soil. However, our method is limited in its ability to quantify the pool of $\mathrm{Hg}$ that may be mobilized via particulate or DOC leaching (Tipping et al., 2011). For this reason, increased $\mathrm{Hg}$ mobility may have been better examined by quantifying $\mathrm{Hg}$ bound to mobile forms of organic matter rather than EHg that may become mobilized after dissolution.

Exchangeable $\mathrm{Hg}$ concentrations in the organic and mineral horizons were regressed with soil $\mathrm{C}, \mathrm{pH}, \%$ clay, latitude, and longitude using stepwise linear regressions and multiple regressions. Exchangeable Hg concentrations in the organic horizons were not significantly correlated with any of the explanatory variables. For the mineral horizons, only soil C and $\mathrm{pH}$ were significantly correlated with EHg. Mineral soil $\mathrm{EHg}$ concentrations were significantly correlated with soil C and $\mathrm{pH}$, together explaining $33 \%$ of the variation. Exchangeable $\mathrm{Hg}$ concentrations were poorly correlated with the six chosen explanatory variables, suggesting that other factors are responsible for the variation. These factors may include types of colloids (inorganic or organic) or character of sorp-

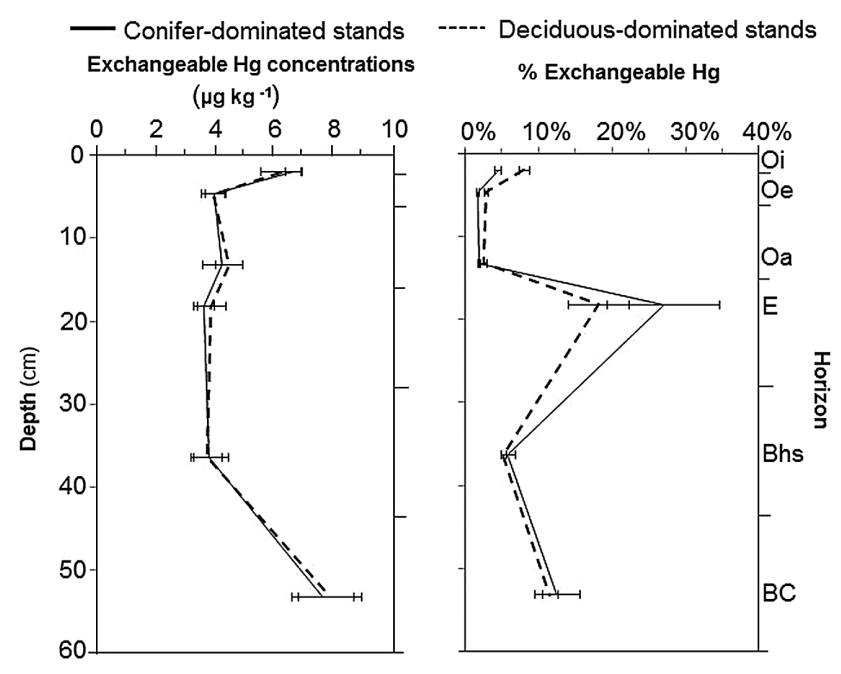

Figure 3. Exchangeable $\mathrm{Hg}$ concentrations and \% exchangeable $\mathrm{Hg}$ in organic and mineral horizons at conifer and deciduous-dominated forest stands. Mean values are given \pm 1 standard error. $\left({ }^{*}\right)$ indicates a significant difference using two-sample $t$ tests $(P<0.05)$.

tion sites on SOM (Schuster, 1991; Gabriel and Williamson, 2004; Essington, 2003).

Our EHg and \% EHg data also provide insight into the sorption and mode of illuviation of $\mathrm{Hg}$. In the Spodosols studied, $\mathrm{Hg}$ was not ion exchangeable. Mercury species were likely immobilized by strong complexation or sorption to organic and inorganic colloids (Schuster, 1991), except for the E horizons. Sesquioxides, such as hematite, goethite, and gibbsite, and SOM in the Bhs horizon can increase Hg complexation (Gabriel and Williamson, 2004). The high proportion of EHg suggests that $\mathrm{Hg}$ is weakly sorbed and is highly mobile due to the lack of SOM and sesquioxides. For the other soil horizons, complexation by organic colloids is most likely to be dominant over inorganic colloids due to the $\mathrm{pH}$ dependency of mineral surfaces in the $\mathrm{Oa}$ and $\mathrm{Bhs}$ 
horizons (Schuster, 1991; Gabriel and Williamson, 2004). The low ionic exchangeability of $\mathrm{Hg}$ agrees with previous studies that the downward transport of $\mathrm{Hg}$ in upland forest soils must be primarily via particulate transport, such as dissolved organic carbon (DOC) or inorganic nanoparticles (Demers et al., 2007; Schwesig and Matzner, 2001; Grigal, 2003; Gabriel and Williamson, 2004; Stankwitz et al., 2012). We observed less acidic soil $\mathrm{pH}$ values at deciduous stands, and thus the future shift in vegetation may raise the soil $\mathrm{pH}$. This could further reduce $\mathrm{Hg}$ exchangeability and SOM mobility by decreasing their solubility, which is $\mathrm{pH}$ dependent (Schuster, 1991; Grigal, 2003; Gabriel and Williamson, 2004).

\subsection{Hg concentrations and pools in aboveground biomass}

\subsubsection{Total $\mathrm{Hg}$ in foliage}

Previous studies have shown that $\mathrm{Hg}$ concentration in foliage varies among tree genera (e.g., St. Louis et al., 2001; Grigal, 2002; Bushey et al., 2008; Juillerat et al., 2012). We expected THg concentrations to be greater in coniferous needles due to their longevity, which coincides with observations of higher $\mathrm{Hg}$ concentrations in conifer needles (Rasmussen et al., 1991; Hall and Louis, 2004; Obrist et al., 2012). We instead found that Abies balsamea and Fagus grandifolia had higher THg concentrations than Picea rubens, Acer spp., and Betula spp. (Fig. 4). Our results match the rankings of $\mathrm{THg}$ concentrations by Rea et al. (2002), Bushey et al. (2008), Juillerat et al. (2012), and Blackwell and Driscoll (2015). This suggests that differences in their physiology beyond vegetation type promote greater $\mathrm{Hg}$ sorption. For example, the $\mathrm{Hg}$ concentration for the foliage of Picea rubens, one of the three coniferous species, was not significantly different than the foliage of Acer spp. and Betula spp., common deciduous genera (Fig. 4). Hence, physiological properties unique to each species, such as leaf roughness, leaf area index, stomatal morphology, and cuticle material, may control $\mathrm{Hg}$ sorption on leaf surfaces and uptake (Browne and Fang, 1978; Weathers et al., 2006; Zhang et al., 2009; Obrist et al., 2012; Juillerat et al., 2012). Blackwell and Driscoll (2015) hypothesized that coniferous vegetation accumulates $\mathrm{Hg}$ at a slower rate than deciduous vegetation, but its longevity and multiple growing seasons is responsible for its higher contribution in litterfall. An additional physiological influence may be that $\mathrm{Hg}$ held on leaf surfaces for Picea spp., Acer spp., and Betula spp. may have greater revolatilization rates than for Abies balsamea and Fagus grandifolia (Hanson et al., 1995).

Mercury concentrations in foliage can also vary temporally, ranging from differences during the growing season (Rea et al., 2002; Juillerat et al., 2012) and among years sampled (Rea et al., 2002; Blackwell and Driscoll, 2015). Foliar $\mathrm{Hg}$ concentrations have been shown to increase an order of magnitude through the growing season (Rea et al., 2002).
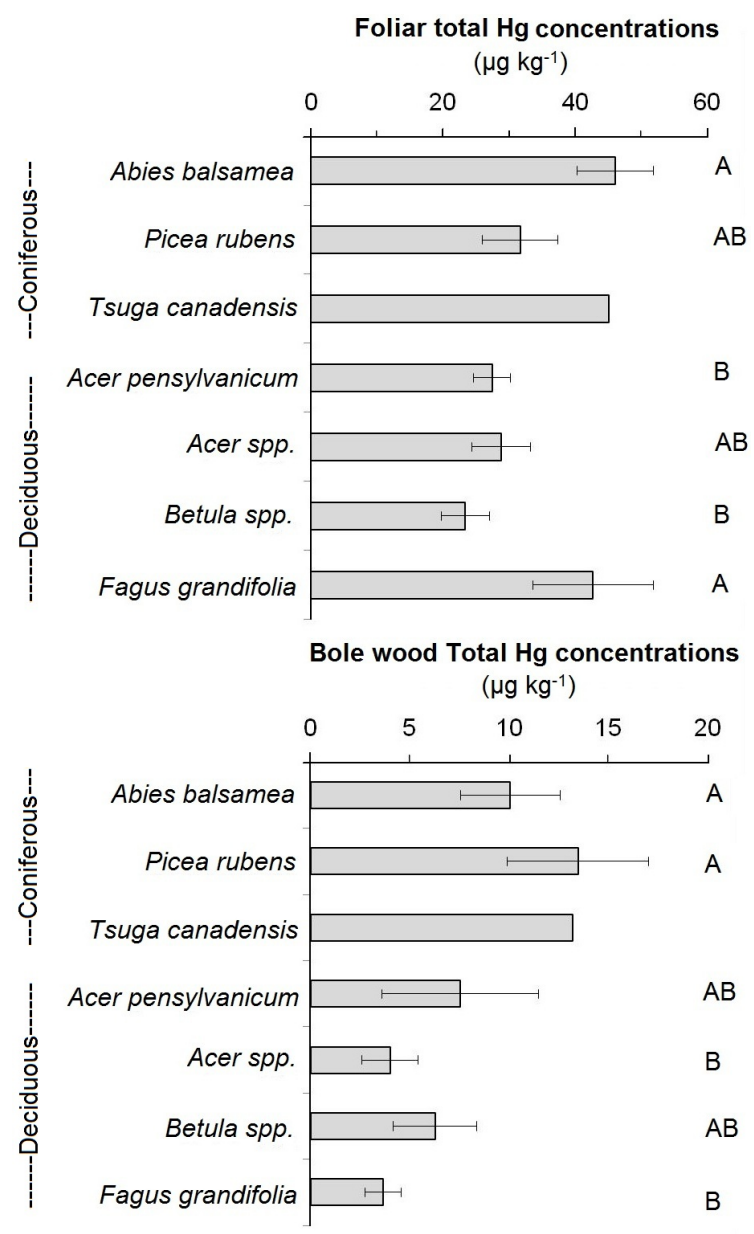

Figure 4. Total $\mathrm{Hg}$ concentrations in dry weight leaves and wood from 2012, 2013, and 2014 forest stand samplings. Mean values are given \pm 1 standard error. Letters (A, B) indicate a significant difference using the Kruskal-Wallis test with post hoc Wilcoxon rank-sum test $(P<0.05)$. Each species/genus $(n=8)$, except Tsuga canadensis $(n=1)$, which was not included in statistical analyses.

Thus, we sampled late-season foliage to estimate the maximum concentration of $\mathrm{Hg}$ obtained by foliage before senescence. In addition to seasonal variation, annual differences in $\mathrm{Hg}$ concentrations have been observed (Rea et al., 2002; Bushey et al., 2008) and were hypothesized to occur from annual variation in uptake and dry deposition onto leaves (Grigal, 2002). However, we did not observe significant differences in THg concentrations in late-season foliage collected in 2012, 2013, and 2014 for any genus. This agrees with results from other studies (e.g., Bushey et al., 2008). In addition, the National Atmospheric Deposition Program (NADP) observed that annual $\mathrm{Hg}$ deposition rates from precipitation and dry deposition were relatively consistent during their monitoring of the region from 2003 to 2013 (NADP, 2007). 


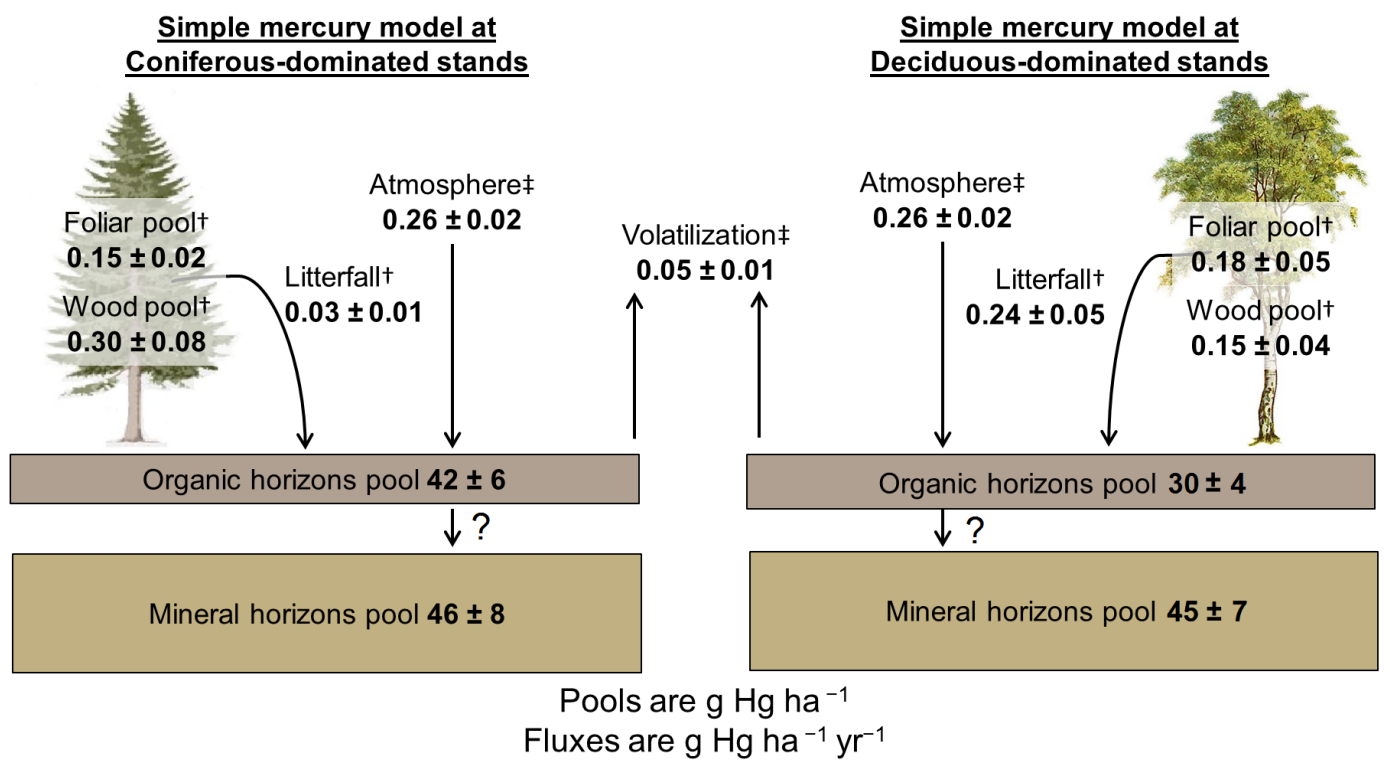

Figure 5. Total $\mathrm{Hg}$ pools in foliage, wood, organic horizons, and mineral horizons at conifer- and deciduous-dominated forest stands. See Sect. 2.5 for explanation of flux estimates. Mean values are given \pm 1 standard error. $\dagger$ Litterfall was estimated using foliar pools and senescence rates for each genus. $\ddagger$ Atmospheric deposition and volatilization rates were interpolated from Miller et al. (2005) and Yu et al. (2014).

\subsubsection{Total $\mathrm{Hg}$ in bole wood}

Bole wood had significantly lower $\mathrm{THg}$ concentrations $\left(8 \pm 4 \mu \mathrm{g} \mathrm{kg}^{-1}\right)$ than foliar $\left(35 \pm 9 \mu \mathrm{g} \mathrm{kg}^{-1}\right)$. Wood THg concentrations ranged from 10 to $50 \%$ of their respective foliar concentrations. Wood THg concentrations were greater for coniferous genera $\left(11.7 \pm 0.8 \mu \mathrm{g} \mathrm{kg}^{-1}\right)$ than for deciduous genera $\left(5.3 \pm 0.7 \mu \mathrm{g} \mathrm{kg}^{-1}\right.$; Fig. 4). These values are similar to bole wood $\mathrm{Hg}$ concentrations in other studies (e.g., Obrist et al., 2012). The greater concentrations of $\mathrm{Hg}$ in coniferous tissue are likely due to ecophysiological properties, such as growth rate and root uptake (Rea et al., 2002). Although root uptake of $\mathrm{Hg}$ is generally considered a small contribution (Aastrup et al., 1991; Grigal, 2002; Rea et al., 2002; Schwesig and Krebs, 2003), it could differ among genera (Beauford et al., 1977) and could possibly be greater for coniferous vegetation. In addition, retention in the xylem could also vary for each genus (Bishop et al., 1998).

\subsubsection{Aboveground biomass total Hg estimation}

The foliar and woody biomass was calculated using 2012 basal area measurements for all trees within the $707 \mathrm{~m}^{2}$ stands and allometric equations for each species (TerMikaelian and Korzukhin, 1997). It must be noted that these values are approximations, and biomass can vary with canopy geometry, tree morphology, and individual fitness of each tree (Ferrari and Sugita, 1996; Luyassaert et al., 2002; Bushey et al., 2008). From the allometric equations, we estimated that coniferous stands had significantly less foliar biomass $\left(1650 \pm 360 \mathrm{~kg} \mathrm{ha}^{-1}\right)$ than deciduous stands $\left(5680 \pm 610 \mathrm{~kg} \mathrm{ha}^{-1}\right)$. Similarly, coniferous stands had significantly less woody biomass $\left(9070 \pm 2220 \mathrm{~kg} \mathrm{ha}^{-1}\right)$ than deciduous stands $\left(24500 \pm 5480 \mathrm{~kg} \mathrm{ha}^{-1}\right)$. The difference in foliar and woody biomass at coniferous and deciduous vegetation was a large but not surprising difference, considering the physiology and canopy structure of deciduous trees (Ferrari and Sugita, 1996).

Mercury pools in the aboveground biomass (foliage and wood) were calculated using averaged 2012, 2013, and $2014 \mathrm{THg}$ concentration data with biomass estimates from allometric equations. Our results in Fig. 5 show that coniferous and deciduous stands do not have significantly different foliar pools of $\mathrm{THg}$ despite significantly more foliar biomass at deciduous stands. However, woody biomass at coniferous stands has a significantly larger $\mathrm{THg}$ pool $\left(0.30 \pm 0.08 \mathrm{~g} \mathrm{ha}^{-1}\right)$ than at deciduous stands $\left(0.15 \pm 0.04 \mathrm{~g} \mathrm{ha}^{-1}\right)$. In spite of two-thirds less woody biomass at coniferous stands than deciduous stands, woody biomass $\mathrm{THg}$ pools at coniferous stands were greater than deciduous stands. Foliar and woody biomass $\mathrm{Hg}$ concentrations can vary annually due to precipitation and temperatures (Risch et al., 2012; Obrist et al., 2012). Moreover, $\mathrm{Hg}$ concentrations can vary with the type of wood sampled (twigs, branches, bark, and bole wood), and vertical location in the canopy can also affect $\mathrm{Hg}$ estimates (Risch et al., 2011; Obrist et al., 2012). However, we believe our estimates of foliar $\mathrm{Hg}$ pools are representative values. For example, the calculated litterfall rates, based on foliar $\mathrm{Hg}$ biomass at the 16 stands, was 
$0.13 \pm 0.04 \mathrm{~g} \mathrm{ha}^{-1} \mathrm{yr}^{-1}$, which matched litterfall rates measured by Risch et al. $\left(2011 ; 0.12 \pm 0.01 \mathrm{~g} \mathrm{ha}^{-1} \mathrm{yr}^{-1}\right)$ and Rea et al. $\left(2002 ; 0.16 \pm 0.02 \mathrm{~g} \mathrm{ha}^{-1} \mathrm{yr}^{-1}\right)$. The litterfall fluxes at coniferous stands $(\sim 10 \%$ of the total $\mathrm{Hg}$ deposited) and deciduous stands ( $\sim 45 \%$ of the total $\mathrm{Hg}$ deposited) are similar to observations by Blackwell and Driscoll (2015) in the northern hardwood forest and Picea spp./Abies spp. forests. The litterfall rates were significantly lower for coniferous stands due to the smaller biomass and greater longevity of the coniferous foliage (Barnes and Wagner, 1981). Our calculated values may be lower than observed values due to the allometric equations used to estimate foliar biomass, as tree morphologies can vary from typical branch architecture.

We find that the $\mathrm{Hg}$ litterfall flux for coniferous stands $\left(0.01-0.08 \mathrm{~g} \mathrm{Hg} \mathrm{ha}^{-1} \mathrm{yr}^{-1}\right)$ is significantly smaller than the atmospheric deposition rate of $\mathrm{Hg}(0.24$ $0.26 \mathrm{~g} \mathrm{Hg} \mathrm{ha}^{-1} \mathrm{yr}^{-1}$ ) based upon estimates from $\mathrm{Yu}$ et al. (2014) for this region (Table S2). Moreover, estimated annual volatilization rates of $\mathrm{Hg}\left(0.02-0.08 \mathrm{~g} \mathrm{Hg} \mathrm{ha}^{-1} \mathrm{yr}^{-1}\right)$ from Yu et al. (2014) are equal to or greater than coniferous litterfall rates. Mercury litterfall flux at deciduous stands $\left(0.10-0.49 \mathrm{~g} \mathrm{Hg} \mathrm{ha}^{-1} \mathrm{yr}^{-1}\right)$ was generally similar to atmospheric deposition rates of $\mathrm{Hg}$ and significantly greater than volatilization rates from $\mathrm{Yu}$ et al. (2014). Although these fluxes were not measured at the eight mountain study sites, they provide an important comparison that the type of vegetation can significantly impact the flux of $\mathrm{Hg}$ to their underlying soils. However, vegetation has been shown to significantly influence throughfall and volatilization rates of $\mathrm{Hg}$ (Demers et al., 2007; Blackwell and Driscoll, 2015). Thus, site-specific throughfall and volatilization rates are needed to fully quantify the effect of vegetation type on abiotic fluxes of $\mathrm{Hg}$ to their underlying soils.

\section{Conclusions}

We conclude that vegetation type significantly influenced $\mathrm{Hg}$ accumulation in the organic horizons of coniferous and deciduous forest stands, but not in the mineral horizons, which were controlled by soil properties. THg concentrations in the $\mathrm{Oi}, \mathrm{Oe}$, and $\mathrm{Oa}$ horizons were greater for coniferous stands than for deciduous stands. The summed organic horizon $\mathrm{THg}$ pools were greater for coniferous stands $\left(53 \pm 10 \mathrm{~g} \mathrm{ha}^{-1}\right)$ than for deciduous stands $\left(30 \pm 6 \mathrm{~g} \mathrm{ha}^{-1}\right)$. We calculated a $28 \%$ lower $\left(12 \mathrm{~g} \mathrm{ha}^{-1}\right) \mathrm{Hg}$ accumulation in soils at deciduous stands than at coniferous stands. Proposed mechanisms for this difference include litter quality, sorption capacity of SOM, and susceptibility for microbial decomposition. Mineral soil THg concentrations and pools did not significantly differ with vegetation type. Instead, soil $\mathrm{C}, \%$ clay, and $\mathrm{pH}$ explained $56 \%$ of the variation in total $\mathrm{Hg}$ concentrations in the mineral soil. The mobility of $\mathrm{Hg}$ did not vary significantly with vegetation type and was weakly explained by soil physicochemical properties. Our empirical data indicate that coniferous vegetation accumulates more $\mathrm{Hg}$ in their underlying soils, primarily in their organic horizons. We calculated a $28 \%$ lower $\left(12 \mathrm{~g} \mathrm{ha}^{-1}\right) \mathrm{Hg}$ accumulation in soils at deciduous stands than at coniferous stands. When extrapolated to the predicted $\sim 2.2$ million ha loss of coniferous forests, the vegetation shift could represent $\sim 27 \mathrm{t}$ less $\mathrm{Hg}$ sequestered in the organic horizons across the region. Further investigations should evaluate the effect of vegetation type on $\mathrm{Hg}$ volatilization, atmospheric deposition, and leaching rates to constrain landscape and regional changes. This will better aid regional and global $\mathrm{Hg}$ models in implementing the effect of shifting vegetation type on future $\mathrm{Hg}$ pools in soils.

\section{The Supplement related to this article is available online at doi:10.5194/bg-12-6737-2015-supplement.}

Acknowledgements. This work was made possible by Dartmouth College Porter Fund 10-001, Northern Studies Grant/Internship, the E.E. Just Program, and the Dartmouth Graduate Alumni Research Award from Dartmouth College. The field component and laboratory analyses would not have been possible without help from Paul Zeitz, James Brofos, Emily Lacroix, and Lars Olaf-Hoger. The authors are thankful for analytical help from Brian Jackson, Janet Towse, and Emily Pierson at the Dartmouth Trace Element Analysis laboratory. Jamie Shanley and Charley Driscoll contributed to project design. We thank the two anonymous reviewers and the associate editor for their detailed and constructive input.

Edited by: D. Obrist

\section{References}

Aastrup, M., Johnson, J., Bringmark, E., Bringmark, I., and Iverfeldt, Å.: Occurrence and transport of mercury within a small catchment area, Water Air Soil Poll., 56, 155-167, 1991.

Amacher, M. C.: Nickel, cadmium, and lead, in: Methods of soil analysis, edited by: Sparks, D. L., Part 3, SSSA Book Ser. 5. SSSA, Madison, WI, 739-768., 1996.

Barnes, B. V. and Wagner, W. H.: Michigan Trees, A guide to the trees of Michigan and the Great Lakes Region, University of Michigan Press, Ann Arbor., 384 pp., 1981.

Beauford, W., Barber, J., and Barringer, A. R.: Uptake and Distribution of Mercury within Higher Plants, Physiol. Plant., 39, 261265, 1977.

Berg, B., Berg, M., Bottner, P., Box, E., Breymeyer, A., Calvo de Anta, R., Couteaux, M., Gallardo, A., Escudero, A., Kratz, W., Madeira, M., Mälkönen, E., Meentemeyer, V., Muñoz, F., Piussi, P., Remacle, J., and Virzo De Santo, A.: Litter mass loss in pine forests of Europe and Eastern United States as compared to actual evapotranspiration on a European scale, Biogeochemistry, 20, 127-153, 1993.

Bennett, D. S., Wittkop, C. A., and Dicken, C. L.: Bedrock Geologic Map of New Hampshire - A Digital Representation of the Lyons 
and others 1997 map and ancillary files: U.S. Geological Survey Data Series 215, scale 1:250000, 2006.

Blackwell, B. D. and Driscoll, C. T.: Deposition of Mercury in Forests along a Montane Elevation Gradient, Environ. Sci. Technol., 49, 5363-5370, 2015.

Bishop K. H., Lee, Y. H., Munthe, J., and Dambrine, E.: Xylem sap as a pathway for total mercury and methylmercury transport from soil to tree canopy in the boreal forest, Biogeochemistry, 40, 101-113, 1998.

Blackwell, B. D., Driscoll, C. T., Maxwell, J. A., and Holsen, T. M.: Changing climate alters inputs and pathways of deposition to forested ecosystems, Biogeochemistry, 119, 215-228, 2014.

Browne, C. L. and Fang, S. C.: Uptake of Mercury Vapor by Wheat: An Assimilation Model, Plant Physiol., 61, 430-433, 1978.

Bushey, J. T., Nallana, A. G., Montesdeoca, M. R., and Driscoll, C. T.: Mercury dynamics of a northern hardwood canopy, Atmos. Environ., 42, 6905-6914, 2008.

Carpi, A. and Lindberg, S. E.: Application of a teflon ${ }^{\mathrm{TM}}$ dynamic flux chamber for quantifying soil mercury flux: Tests and results over background soil, Atmos. Environ., 32, 873-882, 1997.

Chalmers, A. T., Krabbenhoft, D. P., Van Metre, P. C., and Nilles, M. A.: Effects of urbanization on mercury deposition and accumulation in New England, Environ. Pollut., 192, 104-112, 2014.

Crock, J. G.: Mercury, in: Methods of soil analysis, edited by: Sparks, D. L., Part 3, SSSA Book Ser. 5, SSSA, Madison, WI, 769-792, 1996.

Demers, J. D., Driscoll, C. T., Fahey, T. J., and Yavitt, J. B.: Mercury cycling in litter and soil in different forest types in the Adirondack region, New York, USA, Ecol. Appl., 17, 1341-1351, 2007.

Demers, J. D., Blum, J. D., and Zak, D. R.: Mercury isotopes in a forested ecosystem: Implications for air-surface exchange dynamics and the global mercury cycle, Global Biogeochem. Cy., 27, 222-238, doi:10.1002/gbc.20021, 2013.

Doll, C. G., Cady, W. M., Thompson Jr., J. B., and Billings, M. P.: Centennial Geologic Map of Vermont: Vermont Geological Survey, Miscellaneous Map MISCMAP-01, scale 1:250 000, 1961.

do Valle, C. M., Santana, G. P., Augusti, R., Egreja Filho, F. B., and Windmüller, C. C.: Speciation and quantification of mercury in Oxisol, Ultisol, and Spodosol from Amazon (Manaua, Brazil), Chemosphere 58, 779-792, 2005.

Driscoll, C. T., Han, Y-J., Chen, C. Y., Evers, D. C., Lambert, K. F., Holsen, T. M., Kamman, N. C., and Munson, R. K.: Mercury contamination in forest and freshwater ecosystems in the northeastern United States, BioScience, 57, 17-28, 2007.

Eganhouse, R. P., Young, D. R., and Johnson, J. N.: Geochemistry of mercury in Palos Verdos sediments, Environ. Sci. Technol., 12, 1151-1157, 1978.

Essington, M. E.: Soil and water chemistry: An integrative approach, CRC Press, Boca Raton, FL, 311-358., 2003.

Evers, D. C., Han, Y. J., Driscoll, C. T., Kamman, N. C., Goodale, M. W., Lambert, K. F., Holsen, T. M., Chen, C. Y., Clair, T. A., and Butler, T.: Biological mercury hotspots in the Northeastern United States and Southeastern Canada, BioScience, 57, 29-43, 2007.

Ferrari, J. B. and Sugita, S.: A spatially explicit model of leaf litter fall in hemlock-hardwood forests, Can. J. For. Res., 26, 19051913, 1996.
Fitzgerald, W. F., Engstrom, D. R., Mason, R. P., and Nater, E. A.: The case for atmospheric mercury contamination in remote areas, Environ. Sci. Technol., 32, 1-7, 1998.

Foster, D. R.: Land-use history (1730-1990) and vegetation dynamics in central New England, USA, J. Ecol., 80, 753-772, 1992.

Gabriel, M. C. and Williamson, D. G.: Principal biogeochemical factors affecting the speciation and transport of mercury through the terrestrial environment. Environ. Geochem. Health, 26, 421434, 2004.

Gee, G. W. and Bauder, J. W.: Particle-size analysis. In: A. Klute et al., editors, Methods of soil analysis, part 1, 2nd ed., Monogram 9 ASA and SSSA, Madison, WI, 404-408, 1986.

Grigal, D. F.: Inputs and outputs of mercury from terrestrial watersheds: a review, Environ. Rev., 10, 1-39, 2002.

Grigal, D. F.: Mercury Sequestration in Forests and Peatlands: A Review, J. Environ. Qual., 32, 393-405, 2003.

Hall, B. D., and St. Louis, V. L.: Methylmercury and total mercury in plant litter decomposing in upland forests and flooded landscapes, Environ. Sci. Technol., 38, 5010-5021, 2004.

Hanson P. J., Lindberg S. E., Tabberer T. A., Owens J. G., and Kim K.-H.: Foliar Exchange of Mercury Vapor: Evidence for a Compensation Point, Water Air Soil Poll., 80, 373-382, 1995.

Jenkins, J. C., Chojnacky, D. C., Heath, L. S., and Birdsey, R. A.: National-scale biomass estimators for United States tree species. Forest Sci., 49, 12-35, 2003.

Johnson, C. E and Petras, R. J.: Distribution of Zinc and Lead fractions within a Spodosol, Soil Sci. Soc. Am. J., 62, 782-789, 1998.

Juillerat, J. I., Ross, D. S., and Bank, M. S.: Mercury in Litterfall and Upper Soil Horizons in Forested Ecosystems in Vermont, USA, Environ. Toxicol. Chem., 31, 1720-1729, 2012.

Kenefic, L. S. and Nyland, R. D.: Sugar maple height-diameter and age-diameter relationships in an uneven-aged northern hardwood stand, Northern J. Appl. For., 16, 43-47, 1999.

Lamson, N. I.: D.B.H./Crown diameter relationships in mixed Appalachian hardwood stands, USDA Forest Service Research Paper, NE-6 10, 1987.

Lorey, P. and Driscoll C. T.: Historical trends of mercury deposition in Adirondack lakes, Environ. Sci. Technol., 33, 718-722, 1999.

Luyssaert, S., Raitio, H., Vervaeke, P., Mertens, J., and Lust, N.: Sampling procedure for the foliar analysis of deciduous trees, J. Environ. Monit., 4, 858-864, 2002.

Lyons, J. B., Bothner, W. A., Moench, R. H., and Thompson Jr., J. B.: Bedrock Geologic Map of New Hampshire: Reston, VA, US Geological Survey Special Map, $1: 250$ 000, 2 sheets, 1997.

McClaugherty, C. A., Pastor, J., Aber, J. D., and Melillo, J. M.: Forest litter decomposition in relation to soil nitrogen dynamics and litter quality, Ecology, 66, 266-275, 1985.

Miller, E. K., Vanarsdale, A., Keeler, G. ., Chalmers, A., Poissant, L., Kamman, N. C., and Brulotte, R.: Estimation and mapping of wet and dry mercury deposition across northeastern North America, Ecotoxicology, 14, 53-70, 2005.

Moore, T. R., Trofymow, J. A., Taylor, B., Prescott, C. E., Camiré, C., Duschene, L., Fyles, J., Kozak, L., Kranabetter, M., Morrison, I., Siltanen, M., Smith, S., Titus, B., Visser, S., Wein, R., and Zoltai, S.: Litter decomposition rates in Canadian forests, Glob. Change Biol., 5, 75-82, 1999. 
NADP National Atmospheric Deposition Program (NRSP-3): NADP Program Office, Illinois State Water Survey, 2204 Griffith Dr., Champaign, IL 61820, 2007.

Nater, E. A. and Grigal, D. F.: Regional trends in mercury distribution across the Great Lakes states, north central USA, Nature, 358, 139-141, 1992.

Obrist, D., Johnson, D. W., Lindberg, S. E., Luo, Y., Hararuk, O., Bracho, R., Battles, J. J., Dail, D. B., Edmons, R. L., Monson, R. K., Ollinger, S. V., Pallardy, S. G., Pregitzer, K. S., and Todd, D. E.: Mercury distribution across 14 U.S. forests. Part 1: Spatial patterns of concentrations in biomass, litter, and soils, Environ. Sci. Technol., 45, 3974-3981, 2011.

Obrist, D., Johnson, D. W., and Edmonds, R. L.: Effects of vegetation type on mercury concentrations and pools in two adjacent coniferous and deciduous forests, J. Plant Nutr. Soil Sci., 175, 68-77, 2012.

Pokharel, A. K. and Obrist, D.: Fate of mercury in tree litter during decomposition, Biogeosciences, 8, 2507-2521, doi:10.5194/bg8-2507-2011, 2011.

PRISM Climate Group: Prism database: PRISM Climate Group, Oregon State University, Map created 14 October 2012, available at: http://prism.oregonstate.edu (last access: 12 December 2014), 2012.

Pritchett, W. L. and Fisher, R. F.: Properties and Management of Forest Soils, Chapter 4 The Forest Floor, 2nd Ed., John Wiley and Sons, Inc ISBN 0-471-89-572-5, 1987.

Rasmussen, P. E., Mierle, G., and Nriagu, J. O.: The analysis of vegetation for total mercury, Water Air Soil Poll., 56, 379-390, 1991.

Ratcliffe, N. M.: Bedrock geologic map of the Cavendish quadrangle, Windsor County, Vermont: U.S. Geological Survey Geologic Quadrangle Map, scale 1:24 000, 1 sheet, 2000.

Rea, A. W., Lindberg, S. E., Scherbatskoy, T., and Keeler, G. J.: Mercury accumulation in foliage over time in two northern mixed-hardwood forests, Water Air Soil Poll., 133, 49-67, 2002.

Richardson, J. B., Friedland, A. J., Engerbretson, T. R., Kaste, J. M., and Jackson, B. P.: Spatial and vertical distribution of mercury in upland forest soils across the northeastern United States, Environ. Pollut., 182, 127-134, 2013.

Richardson J. B., Friedland A. J., Kaste J. M., and Jackson B. P.: Forest floor lead changes from 1980 to 2011 and subsequent accumulation in the mineral soil across the northeastern United Sates, J. Environ. Qual., 43, 926-935, doi:10.2134/jeq2013.10.0435, 2014

Richardson, J. B., Görres J. H., Friedland, A. J., and Jackson B. P.: Trace Metals and Metalloids in Forest Soils and Invasive Earthworms in Northern New England, USA, Soil Biol. Biochem., 85, 190-198, 2015.

Rimmer, C. C., Miller E. K., McFarland K. P., Taylor, R. J., and Faccio, S. D.: Mercury bioaccumulation and trophic transfer in the terrestrial food web of a montane forest, Ecotoxicology, 19, 697-709, 2010.

Risch, M. R., DeWild, J. F., Krabbenhoft, D. P., Kolka, R. K., and Zhang, L.: Litterfall mercury dry deposition in the eastern USA, Environ. Pollut., 161, 284-290, 2012.

Schlüter, K.: Review: evaporation of mercury from soils. An integration and synthesis of current knowledge, Environ. Geol., 39, 249-271, 2000
Schuster, E.: The behavior of mercury in soil with special emphasis on complexation and adsoprtion processes - a review of the literature, Water Air Soil Poll., 56, 667-680, 1991.

Schwesig, D. and Matzner, E.: Dynamics of mercury and methylmercury in forest floor and runoff of a forested watershed in Central Europe, Biogeochemistry, 53, 181-200, 2001.

Schwesig, D. and Krebs, O.: The role of ground vegetation in the uptake of mercury and methylmercury in a forest ecosystem, Plant Soil, 253, 445-455, 2003.

Siccama, T. G.: Vegetation, soil, and climate on green mountains of Vermont, Ecol. Monogr., 44, 325-349, 1974.

Smith-Downey, N. V., Sunderland E. M., and Jacob, D. J.: Anthropogenic impacts on global storage and emissions of mercury from terrestrial soils: insights from a new global model, J. Geophys. Re., 115, G03008, doi:10.1029/2009JG001124, 2010.

Soil Survey Staff: Keys to Soil Taxonomy, 11th ed., USDA-Natural Resources Conservation Service, Washington, DC, 2010.

Soil Survey Staff: Natural Resources Conservation Service, United States Department of Agriculture, Web Soil Survey, available online at: http://websoilsurvey.nrcs.usda.gov/ (last access: 22 April 2012), 2014

St. Louis, V. J., Rudd, W. M., Kelly, C. A., Hall, B. D., Rolfhus, K. R., Scott, K. J., Lindberg, S. E., and Dong, W.: Importance of the forest canopy to fluxes of methyl mercury and total mercury to boreal ecosystems, Environ. Sci. Technol., 35, 3089-3098, 2001.

Stankwitz, C., Kaste, J. M., and Friedland, A. J.: Threshold increases in soil lead and mercury from tropospheric deposition across an elevational gradient, Environ. Sci. Technol., 46, 80618068, doi:10.1021/es204208w, 2012.

Streets, D. G., Devane, M. K., Lu, Z., Bond, T. C., Sunderland, E. M., and Jacob D. J.: All-time releases of mercury to the atmosphere from human activities, Environ. Sci. Technol., 45, 1048510491, 2011

Talbot, J. M., Yelle, D. J., Nowick, J., and Treseder, K. K.: Litter decay rates are determined by lignin chemistry, Biogeochemistry, 108, 279-295, 2012.

Tang, G. and Beckage, B.: Projecting the distribution of forests in New England in response to climate change, Divers. Distribut. 16, 144-158, 2010.

Tang, G., Beckage, B., and Smith, B.: The potential transient dynamics of forests in New England under historical and projected future climate change, Climatic Change, 114, 357-377, 2012.

Teck, R. M. and Hilt, D. E.: Individual-Tree Diameter Growth Model for the Northeastern United States. Research Paper NE649, Radnor, PA: US, Department of Agriculture, Forest Service, Northeastern Forest Experiment Station, 11 pp., 1991.

Ter-Mikaelian, M. T. and Korzukhin, M. D.: Biomass equations for sixty-five North American tree species, Forest Ecol. Manage.t, 97, 1-24, 1997.

Tipping, E., Wadsworth, R. A., Norris, D. A., Hall, J. R., and Ilyin. I.: Long-term mercury dynamics in UK soils, Environmental Pollution, 159, 3474-3483, 2011.

Townsend, J. and Driscoll, C. T.: Red-backed salamander (Plethodon cinereus) as a bioindicator of mercury in terrestrial forests of the northeastern United States, Ecol. Indicators, 34, 168-171, 2013.

USEPA: US Environmental Protection Agency: National Emission Standards for Hazardous Air Pollutants from Coal- and Oilfired Electric Utility Steam Generating Units and Standards of 
Performance for Fossil-Fuel-Fired Electric Utility, IndustrialCommercial-Institutional, and Small Industrial-CommercialInstitutional Steam Generating Units EPA-HQ-OAR-2009-0234; EPA-HQ-OAR-2011-0044, 2011.

Weathers, K. C., Simkin, S. M., Lovett, G. M., and Lindberg, S. E.: Empirical modeling of atmospheric deposition in mountainous landscapes, Ecol. Appl., 16, 1590-1607, 2006.

Whittaker, R. H., Bormann, F. H., Likens, G. E., and Siccama, T. G.: The Hubbard Brook Ecosystem Study: forest biomass and production, Ecol. Monogr., 44, 233-254, 1974.
Yu, X., Driscoll, C. T., Warby, R. A. F., Montesdeoca, M., and Johnson, C. E.: Soil mercury and its response to atmospheric mercury deposition across the northeastern United States, Ecol. Appl., 24, 812-822, 2014.

Zhang, L., Wright, L. P., and Blanchard, P.: A review of current knowledge concerning dry deposition of atmospheric mercury, Atmos. Environ., 43, 5853-5864, 2009. 